\title{
Tree diversity and phytogeographical patterns of tropical high mountain rain forests in Central Sulawesi, Indonesia
}

\author{
Heike Culmsee $\cdot$ Ramadhanil Pitopang • Hardianto Mangopo • \\ Sahar Sabir
}

Received: 3 August 2010/Accepted: 11 February 2011/Published online: 4 March 2011

(C) The Author(s) 2011. This article is published with open access at Springerlink.com

\begin{abstract}
Tropical high mountain forests in Lore Lindu National Park, Sulawesi, Indonesia, were described by their floristic composition and the importance of tree families (Family importance values, FIV), based on tree inventories conducted on 4 plots (each $0.24 \mathrm{ha}$ ) in old-growth forest stands at c. 1800 and $2400 \mathrm{~m}$ a.s.l. (mid- and upper montane elevations). To identify general patterns and regional peculiarities of the forests in the SE Asian and SW Pacific context, the biogeography of the tree species was analysed using distribution records. Out of the total of 87 tree species, only 18 species were found at both elevational zones. The discovery of new species and new distribution records $(28 \%$ of the data set) highlights the deficiencies in the taxonomic and distribution data for Sulawesi. Sulawesi endemism rate was 20\%. In the mid-montane Fagaceae-Myrtaceae forests, Lithocarpus spp. (Fagaceae) were overall important (4 spp. occupying around half of the total basal area) and the Myrtaceae the most species rich (8 spp.), thus showing typical features of Malesian montane forests. The upper montane conifer-Myrtaceae forest contained several high mountain tree taxa and showed affinity to the forests of New Guinea. The mountain flora comprised both eastern and western Malesian elements, with the nearest neighbouring islands Borneo and Maluku both sharing species with Sulawesi, reflecting the complex palaeogeography of the island. A separate analysis showed the midmontane forest to possess greatest biogeographical affinity to Borneo/western Malesia, and the upper montane forest had a number of typical elements of Papuasia/eastern Malesia and the Phillipines, which may be a result of historical patterns in land connection and the emergence of mountain ranges.
\end{abstract}

H. Culmsee ( $₫)$

Vegetation and Phytodiversity Analysis, Albrecht von Haller Institute of Plant Sciences,

University of Göttingen, Untere Karspüle 2, 37073 Göttingen, Germany

e-mail: heike.culmsee@bio.uni-goettingen.de

R. Pitopang

Department of Biology, Faculty of Mathematics and Natural Sciences, Tadulako University,

Palu, Sulawesi Tengah 94118, Indonesia

H. Mangopo $\cdot$ S. Sabir

Department of Forest Management, Faculty of Forestry, Tadulako University,

Palu, Sulawesi Tengah 94118, Indonesia 
Keywords Biogeography - Celebes · Endemism - Fagaceae FIV · Malesia - Montane rain forest · Mountain flora $\cdot$ Phyllocladaceae $\cdot$ Podocarpaceae $\cdot$ Sulawesi $\cdot$ Tree diversity

\section{Introduction}

We still have a very poor understanding of the distribution of known taxa in the biogeographically complex Malesian region (Webb et al. 2010). Located in the Wallacean subregion of Malesia, Sulawesi is one of the most poorly known ecoregions (Cannon et al. 2007), but has been highlighted as a globally important biodiversity hotspot and conservation area (Myers et al. 2000; Sodhi et al. 2004). Plant species collection rates on the island are among the lowest in Indonesia. Plot-based tree inventories have to date been restricted to hill and submontane elevational belts (Kessler et al. 2005; Culmsee and Pitopang 2009), and the high mountain flora of the island is only known from a single, nonquantitative case study dating from the 1970s (van Balgooy and Tantra 1986).

Sulawesi has a steep topography with about $20 \%$ land cover above $1000 \mathrm{~m}$ a.s.l. Most of the forests remaining in good or old-growth condition are situated in mountain areas at montane elevations (Cannon et al. 2007). In the southeast Asian natural rain forest vegetation, three major zones, the tropical, montane and subalpine zones, have been delimited based on floristic distribution patterns and major shifts of vascular plant species along the elevational gradient (van Steenis 1972, 1984). The high species turn-over along the elevational gradient is associated with the linear decline in air temperature with increasing elevation (Körner 2000, 2007). Mountain forests in Sulawesi mainly cover the montane zone ranging from 1000 to $2400 \mathrm{~m}$ elevation, including a submontane subzone at 1000-1500 m. The natural montane vegetation of Sulawesi has been described as closed, tall-stemmed forest showing decreasing stem density and canopy height with increasing elevation (Culmsee et al. 2010). Above $2000 \mathrm{~m}$ a.s.l., there is also an increasing quantity of mosses (Frahm and Gradstein 1991). Southeast Asian forests of the montane zone have been broadly characterised as evergreen Lauro-Fagaceous forests with high diversity and abundance of tropical Fagaceae (Ashton 1988, 2003; Ohsawa 1993; Soepadmo 1972; Corlett 2007). In mountain forests of Central Sulawesi, the Fagaceae make up to $>50 \%$ of the aboveground biomass; tree family abundances associated with biogeographical and phylodiversity patterns steadily change along the elevational gradient (Culmsee et al. 2010).

As part of Wallacea, the island of Sulawesi is positioned at the biogeographical crossroads between East Asia and Australasia (Wallace 1869), and between the Laurasian and Gondwanan continents (Primack and Corlett 2006). It has a long history as a large oceanic island. Extremely high rates of plate convergence resulted in the island's configuration of partly southeast Asian and partly southwest Pacific origin (Hall 2009). Roos et al. (2004) attributed the unusual biogeographical composition of the flora of Sulawesi, comprising eastern and western Malesian centred floristic elements, to its complex geological history, but found relatively low species richness and endemism rates in comparison to the bigger Malesian islands which had land connections on the Sunda and Sahul shelves.

In this article, the tree diversity of mountain rain forests was studied at Mt Nokilalaki and Mt Rorekautimbu, two peaks situated within Lore Lindu National Park, Central Sulawesi. This is the first study in Sulawesi that includes both thorough floristic and quantitative, plot-based tree diversity data from high montane old-growth forests. The 
purpose of this study is to contribute to a better knowledge of the composition and origin of the high mountain tree flora of Sulawesi. The lack of taxonomic data from this region suggest a high number of new species distribution records to be discovered. Specifically, we analysed the tree species richness, species composition and tree family importance values (FIV) based on quantitative plot data comparing forests from two different elevational belts. In addition, phytogeographical patterns were investigated by comparing the forests at different elevations and by considering endemism rates and biogeographical distribution patterns of the tree species in the Malesian context.

\section{Methods}

Study area

The study sites were located in primary forests on the slopes of Mt Nokilalaki (S $01^{\circ} 14.6^{\prime}, \mathrm{E}$ $120^{\circ} 09.2^{\prime}$, GC-WGS 84) and Mt Rorekautimbu (S 01 ${ }^{\circ} 16.8^{\prime}$, E $120^{\circ} 18.5^{\prime}$, GC-WGS 84), which are among the highest peaks in the Lore Lindu National Park, Central Sulawesi, Indonesia (Fig. 1). The forest conditions have been classified as good to old-growth (Cannon et al. 2007). Mid-montane forests were investigated at Mt Nokilalaki at c. $1800 \mathrm{~m}$ elevation (plot N2 at $1800 \mathrm{~m}$ a.s.l., plot N1 at $1850 \mathrm{~m}$ a.s.l.). The flora of Mt Rorekautimbu is known from the floristic studies of van Balgooy and Tantra (1986) who explored the mountain slope starting from $1700 \mathrm{~m}$ up to the summit at $2450 \mathrm{~m}$ elevation. They described species-rich Fagaceae-Myrtaceae and Agathis forests at 1700-2000 m a.s.l., but these have been largely deforested since then and only the upper montane crest has remained old-growth. The upper montane old-growth forest remnants with large amounts of moss on the forest floor and the trees ('mossy forest') at Mt Rorekautimbu were investigated at c. $2400 \mathrm{~m}$ elevation (plot R1 at $2350 \mathrm{~m}$ a.s.1., plot R2 at $2380 \mathrm{~m}$ a.s.1.). The soil types were histic cambisols (FAO 2006) developed on granite rock on level terrain on gently sloping ridges or mid-slope terraces. Both sites were characterised by a perhumid climate with at most 2 months per year receiving less than $100 \mathrm{~mm}$ rainfall (WorldClim 2006), and with mean annual temperature of $17.9^{\circ} \mathrm{C}$ in the mid-montane and of $14.1^{\circ} \mathrm{C}$ in the upper montane forests.

Field sampling

Plot-based tree inventories were carried out from July to August 2007. Plot size was $40 \times 60 \mathrm{~m}(0.24 \mathrm{ha})$ divided up into a $10 \times 10 \mathrm{~m}$ grid. All trees of diameter at breast height (d.b.h. at $1.3 \mathrm{~m}) \geq 10 \mathrm{~cm}$ were surveyed. Within each of the $10 \times 10 \mathrm{~m}$, one $5 \times 5 \mathrm{~m}$-sized subplot was surveyed ( 0.06 ha per plot) to additionally study understorey trees of d.b.h. 2-9.9 cm. All trees were permanently tagged, pre-identified and structural parameters recorded (d.b.h., total height). At both mountains, two plots were installed at about $1000 \mathrm{~m}$ distance from each other, i.e. 0.48 ha were sampled in each forest type. Rarefaction analysis (Gotelli and Colwell 2001) confirmed that the area was sufficiently large to represent the species pool at both sites (Culmsee et al. 2010).

Tree species identification

Tree species identification was based on about 1000 specimens collected from tagged trees and supplementary trees in flower or fruit. Specimens were deposited at the herbaria of Göttingen (GOET), Palu (CEB), Leiden (L) and London (K). The identification was carried 

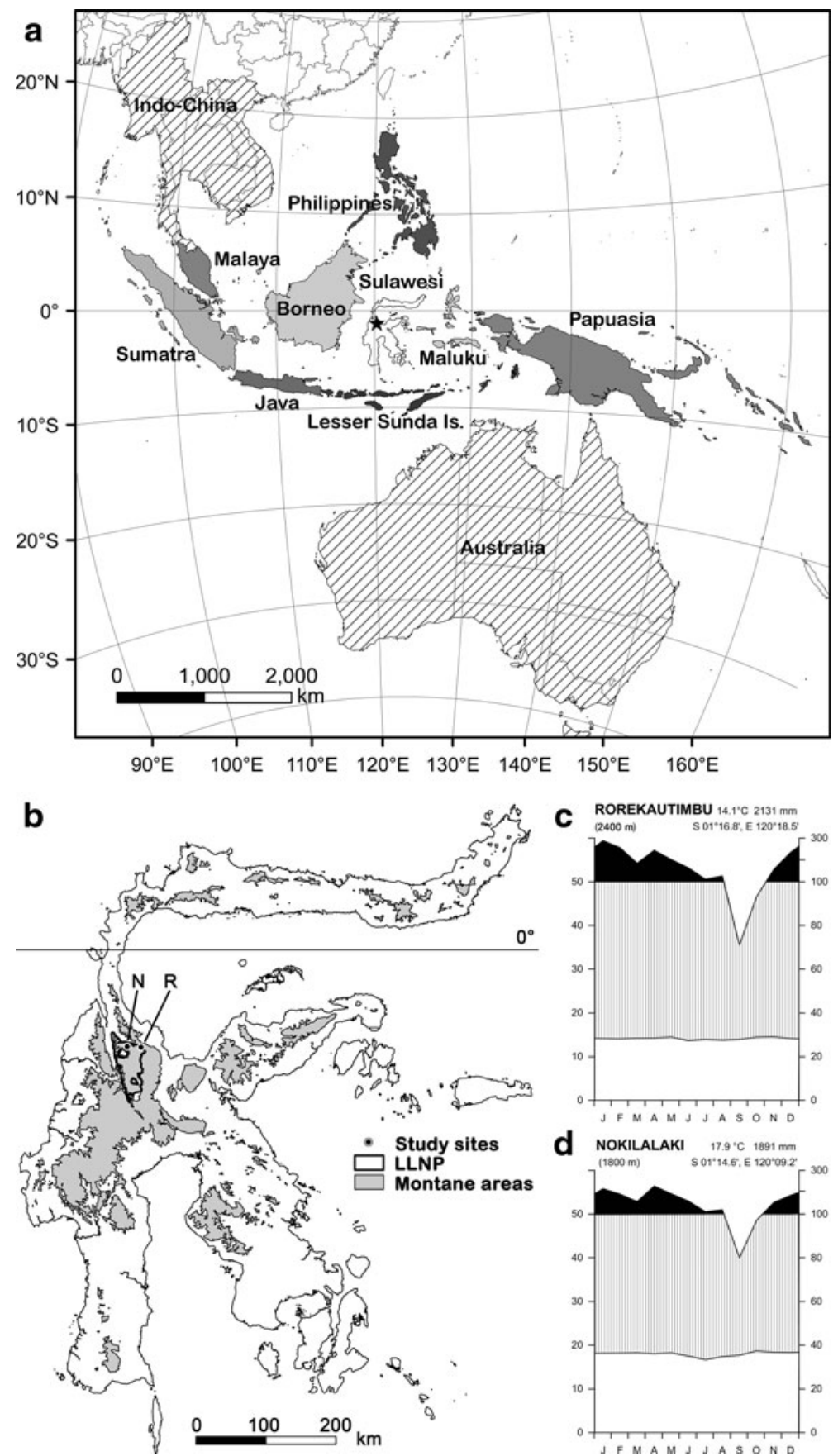

out by the first author using the collection of the National Herbarium of the Netherlands (L) as a reference. M.J.E. Coode (K) identified the species within Elaeocarpaceae. Taxa difficult to identify to species, especially in the Myrtaceae, were distinguished as separate 
Fig. 1 a The study area (star) in Sulawesi, Indonesia, in the centre of the phytogeographical region Malesia which includes nine subdivisions from Malaya to Papuasia (after Brummitt 2001), b location of the study sites at Mt Rorekautimbu (R, plots R1, R2, c. 2400 m a.s.1.) and Mt Nokilalaki (N, plots N2, N1, c. 1800 m a.s.1.), Lore Lindu National Park (LLNP); grey areas indicate montane elevations $>1000 \mathrm{~m}$ a.s.1., and climate diagrams of $\mathbf{c}$ Mt Rorekatutimbu and $\mathbf{d}$ Mt Nokilalaki; climate data extracted from the WorldClim model (Hijmans et al. 2005; WorldClim 2006). Maps with universal transverse mercator (UTM) projection 51 south (WGS 1984)

species based on morphology of vegetative characters (leaves, twigs and bark). Nomenclature of species followed IPNI (2009). Designation of taxa to families followed Stevens (2001 onwards). Out of 1288 investigated tree individuals, 1238 were identified to species (including 272 individuals of Myrtaceae assigned to morpho-species), 31 to genus level, 10 to family level. Only 9 individuals remained unidentified and were excluded from further analyses.

\section{Stand structural analysis}

Significant differences in individual-based traits (canopy height based on trees $\geq 20 \mathrm{~cm}$ d.b.h., tree height and d.b.h. based on trees $\geq 10 \mathrm{~cm} \mathrm{d.b.h.)} \mathrm{between} \mathrm{the} \mathrm{four} \mathrm{plots} \mathrm{were}$ tested with the nonparametric Behrens-Fisher test for multiple comparisons (Munzel and Hothorn 2001) and the Wilcoxon rank-sum test for the comparison of two samples using the npmc and base packages in the R 2.11.1 software (R Development Core Team 2010).

\section{Tree diversity analysis}

Tree inventory data were analysed for large trees $(\geq 10 \mathrm{~cm}$ d.b.h.) and all trees $(\geq 2 \mathrm{~cm}$ d.b.h.), and were related to the size of 1 ha plots. The estimation of the number of tree species $\mathrm{ha}^{-1}$ involved sample-based rarefaction analysis $($ MaoTau $=$ expected species accumulation curves, randomised by samples without replacement, 999 Monte Carlo permutations) based on the species recorded in 0.01 ha sub-plots per site, and was computed using EstimateS version 8 (Colwell 2006) followed by regression analysis for the extrapolation to a 1 ha area. On the family level, stem density ha $^{-1}$ (based on the enumeration of individuals) and basal area $\mathrm{ha}^{-1}$ (based on the d.b.h. measured) were calculated. The family importance value (Mori et al. 1983) was used to assess the contribution of each family to the stand. FIV combines relative richness (number of species), relative density (number of individuals) and relative dominance (basal area) into one value. Similarity of the 4 plots was analysed for the presence/absence data using the VEGDIST and ADONIS functions of the vegan package in the R software. Families and plots in the FIV table were sorted by indirect gradient analysis (Detrended correspondence analysis, DCA) using the Canoco 4.5 package (ter Braak and Šmilauer 2002).

Phytogeographical pattern analysis

Phytogeographical pattern analysis followed the division of Malesia into nine major regions (Malay Peninsula, Sumatra, Java, Borneo, the Philippines, Sulawesi, Moluccas, Lesser Sunda Islands, and Papuasia with New Guinea at its core), supplemented by records from outside Malesia (Indo-China, and Australia including the Oceanic islands), using the phytogeographical concept of regions and their subdivisions of Brummitt (2001). 
The designation of new records for Sulawesi or Central Sulawesi were based on comparison with the Checklist of woody plants of Sulawesi (Keßler et al. 2002) and Culmsee and Pitopang (2009).

Species distribution records were collated from published Flora Malesiana revisions (Backer 1954; van Steenis 1954, 1986; Sleumer 1958, 1971, 1972, 1976, 1986; Holttum 1963; Ding Hou 1972a, b; Jacobs 1972; van der Linden 1972; Nooteboom 1977, 1985, 2005; Scott 1978; Airy Shaw 1983; Keng 1984; Philipson 1986; Verdcourt 1986; Maxwell and Veldkamp 1990; Kalkman 1993; Huang 1997; Fortune Hopkins and Hoogland 2002; Berg and Corner 2005; Middleton 2007) and were complemented and updated by checking the collections at the National Herbarium of the Netherlands, Leiden (L, last accessed in March 2008). Trees that were not identified to species-level were recorded for Sulawesi and designated as unknown wider distribution. For each of the two forest types, the total number of distribution records for each region was calculated considering all trees $(\geq 2 \mathrm{~cm}$ d.b.h.).

The probability that the nearest neighbour occurrence of each tree species was located in Sulawesi or in one of the other phytogeographical subdivisions of Malesia or outside Malesia was investigated by a discrete probability distribution analysis (Poisson probability density function) using the R software. Thereby, nearest neighbour distances were calculated as the Euclidean distances between the study area and the centroids of the other regions using ArcGIS-ArcInfo v. 9.2 software (ESRI 2006-2009); the seven nearest neighbour islands, including Sulawesi for endemics, remaining after all tree species distributions were investigated (based on the 71 tree species assigned to valid species names), were converted to discrete data ordered by ascending distance.

The likelihood that one of the two studied forest areas $(N, R)$ included more tree species with nearest neighbour distance to one of the seven islands than the other was tested by a null-model programmed in the $\mathrm{R}$ software. For this, the number of tree species of each community ( $N=42$ spp., $R=45 \mathrm{spp}$.) was randomly sampled 1000 times from the combined $N+R$ species pool (71 out of 87 tree taxa identified to species level), the lower 25 and the upper 975 values were evaluated for each nearest neighbour island as equivalents to the patterns expected in the absence of a phytogeographical peculiarity (i.e. the $P$-level $>5 \%$ ), and the results were compared to the observed communities.

\section{Results}

\section{Forest structure}

The upper canopy height and mean tree height of the montane forests was very similar (canopy height of $22 \mathrm{~m}$, mean tree height $17 \mathrm{~m}$ of large trees $\geq 10 \mathrm{~cm}$ d.b.h.), with exception of the upper montane forest plot R1, which was shorter (Table 1). The higher structural variability between the two upper montane forest plots was accompanied by differences in the proportion of angiosperm and gymnosperm trees and tree ferns. In R2 fewer but larger angiosperm tree individuals reached the height of the mid-montane forest plots, and large gymnosperm trees reached on average $>20 \mathrm{~m}$ height. In contrast, in the R1 plot, which had the overall highest stem density, angiosperm trees were smaller and more numerous and tree ferns with a generally small stature ( $7 \mathrm{~m}$ mean height) made up $10 \%$ of the trees $\geq 10 \mathrm{~cm}$ d.b.h. While mean d.b.h. was similar in all plots, basal area was generally higher in the upper montane forests than in the mid-montane forests. 
Table 1 Stand structural parameters and tree richness on family, genus and species levels of four 0.24 ha plots in mid- and upper montane forests

\begin{tabular}{|c|c|c|c|c|}
\hline \multirow[t]{2}{*}{ Plot number } & \multicolumn{2}{|c|}{$\begin{array}{l}\text { Mid-montane forest } \\
\text { Mt Nokilalaki } \\
\text { (c. } 1800 \mathrm{~m} \text { a.s.l.) }\end{array}$} & \multicolumn{2}{|c|}{$\begin{array}{l}\text { Upper montane forest } \\
\text { Mt Rorekautimbu } \\
\text { (c. } 2400 \mathrm{~m} \text { a.s.1.) }\end{array}$} \\
\hline & $\mathrm{N} 2$ & N1 & R1 & R2 \\
\hline Elevation (m a.s.l.) & 1800 & 1850 & 2350 & 2380 \\
\hline \multicolumn{5}{|l|}{ Stand structure } \\
\hline Total of sampled stems $\geq 2 \mathrm{~cm}$ d.b.h. on 0.24 ha & 289 & 320 & 360 & 319 \\
\hline Stems of all trees $\geq 10 \mathrm{~cm}$ d.b.h. ( 0.24 ha) & 140 & 193 & 246 & 176 \\
\hline Stems of angiosperm trees $\geq 10 \mathrm{~cm}$ d.b.h. ( $0.24 \mathrm{ha})$ & 140 & 193 & 160 & 115 \\
\hline $\begin{array}{l}\text { Stems of gymnosperm trees } \geq 10 \mathrm{~cm} \text { d.b.h. } \\
(0.24 \text { ha })\end{array}$ & 0 & 0 & 60 & 60 \\
\hline Stems of tree ferns $\geq 10 \mathrm{~cm}$ d.b.h. ( $0.24 \mathrm{ha})$ & 0 & 0 & 26 & 1 \\
\hline Stems of all trees $2-9.9 \mathrm{~cm}$ d.b.h. $(0.06 \mathrm{ha})$ & 149 & 127 & 114 & 143 \\
\hline Stem density (all trees $\geq 10 \mathrm{~cm}$ d.b.h., $n \mathrm{ha}^{-1}$ ) & 583 & 804 & 1025 & 733 \\
\hline Stem density (all trees $\geq 2 \mathrm{~cm}$ d.b.h., $n$ ha $^{-1}$ ) & 3067 & 2921 & 2908 & 3117 \\
\hline Upper canopy height (m) & $22.2 \pm 0.8^{\mathrm{a}}$ & $22.4 \pm 0.6^{\mathrm{a}}$ & $18.3 \pm 0.6^{\mathrm{b}}$ & $22.4 \pm 0.8^{\mathrm{a}}$ \\
\hline Mean height of all trees $\geq 10 \mathrm{~cm}$ d.b.h. $(\mathrm{m})$ & $17.2 \pm 0.5^{\mathrm{a}}$ & $17.8 \pm 0.4^{\mathrm{a}}$ & $14.6 \pm 0.3^{\mathrm{b}}$ & $17.6 \pm 0.5^{\mathrm{a}}$ \\
\hline $\begin{array}{l}\text { Mean height of angiosperm trees } \\
\geq 10 \mathrm{~cm} \text { d.b.h. }(\mathrm{m})\end{array}$ & $17.2 \pm 0.5^{\mathrm{a}, \mathrm{c}}$ & $17.8 \pm 0.4^{\mathrm{a}}$ & $14.7 \pm 0.3^{\mathrm{b}}$ & $16.2 \pm 0.5^{\mathrm{c}}$ \\
\hline $\begin{array}{l}\text { Mean height of gymnosperm trees } \\
\geq 10 \mathrm{~cm} \text { d.b.h. }(\mathrm{m})\end{array}$ & 0 & 0 & $17.2 \pm 0.3^{\mathrm{a}}$ & $20.5 \pm 0.5^{\mathrm{b}}$ \\
\hline Mean height of tree ferns $\geq 10 \mathrm{~cm}$ d.b.h. (m) & 0 & 0 & $7.4 \pm 0.3$ & (7.1) \\
\hline Mean d.b.h. of trees $\geq 10 \mathrm{~cm}$ d.b.h $(\mathrm{cm})$ & $22.7 \pm 1.2^{\mathrm{a}}$ & $21.4 \pm 0.9^{\mathrm{a}}$ & $21.6 \pm 0.8^{\mathrm{a}}$ & $23.0 \pm 1.1^{\mathrm{a}}$ \\
\hline Basal area of trees $\geq 10 \mathrm{~cm}$ d.b.h. $\left(\mathrm{m}^{2} \mathrm{ha}^{-1}\right)$ & 33.3 & 38.6 & 50.8 & 42.1 \\
\hline Basal area of trees $\geq 2$ cm d.b.h. $\left(\mathrm{m}^{2} \mathrm{ha}^{-1}\right)$ & 38.0 & 43.1 & 55.4 & 47.5 \\
\hline \multicolumn{5}{|l|}{ Richness of tree taxa } \\
\hline Number of tree families $\geq 10 \mathrm{~cm}$ d.b.h. & 13 & 16 & 23 & 18 \\
\hline Number of tree families $\geq 2 \mathrm{~cm}$ d.b.h. & 23 & 24 & 24 & 22 \\
\hline Number of tree genera $\geq 10 \mathrm{~cm}$ d.b.h. & 13 & 19 & 30 & 24 \\
\hline Number of tree genera $\geq 2 \mathrm{~cm}$ d.b.h. & 26 & 27 & 32 & 28 \\
\hline Number of tree species $\geq 10 \mathrm{~cm}$ d.b.h. & 22 & 30 & 40 & 25 \\
\hline Number of tree species $\geq 2 \mathrm{~cm}$ d.b.h. & 38 & 39 & 43 & 33 \\
\hline $\begin{array}{l}\text { Estimated number of tree species } \\
\geq 10 \mathrm{~cm} \text { d.b.h. } \mathrm{ha}^{-1}\end{array}$ & $30 \pm 4$ & $40 \pm 6$ & $55 \pm 3$ & $34 \pm 4$ \\
\hline $\begin{array}{l}\text { Estimated number of tree species } \\
\geq 2 \mathrm{~cm} \text { d.b.h. ha }{ }^{-1}\end{array}$ & $51 \pm 4$ & $52 \pm 4$ & $59 \pm 3$ & $44 \pm 3$ \\
\hline
\end{tabular}

Mt Nokilalaki (N2, N1) and Mt Rorekautimbu (R1, R2), Lore Lindu National Park, Sulawesi

Different superscripted letters indicate significant differences in individual-based traits between the sites $(P \leq 0.05$, non-parametric Behrens-Fisher test for multiple comparisons and Wilcoxon rank-sum test for the comparison between two plots)

\section{Species richness and floristic similarities}

In total, 87 tree species of 44 vascular plant families were sampled, of which 73 species were present as large trees (see Table 4 in Appendix). The most species-rich families were 
the Myrtaceae (11 spp.), Theaceae (6 spp.) and Myrsinaceae (5 spp.). Considering all trees, 18 tree species were found at both elevational zones, of which 7 were common to all plots.

Taxonomic richness varied considerably between plots (Table 1). Both total counts and estimated number of tree species $\mathrm{ha}^{-1}$ indicated that the diversity of large trees was on average higher in the upper montane forests than in the mid-montane forest, but that the mid-montane forests were more enriched by understorey trees than the upper montane forests. This resulted in a total decline in tree species richness towards the forest at higher elevations.

With $69.1 \%$ similarity (Sørensen index), the upper montane forests (R1, R2) were more similar in species composition than the mid-montane forests (N1, N2) which showed $60.2 \%$ similarity. Between plots at mid- and upper montane elevations similarity was lower $(31.5 \% \pm 4.8)$, but ADONIS results testing species presence against elevation were not significant $(P=0.08)$, because of the high number of rare species (43, rare meaning restricted to one plot).

\section{Community composition}

The tree communities were Fagaceae-Myrtaceae forests at mid-montane elevations and conifer-Myrtaceae forests at upper montane elevations (Table 2). The FIV indicated high importance of the Myrtaceae, Theaceae, Fagaceae, Symplocaceae and Rubiaceae at both elevational zones.

At mid-montane elevations, in the Fagaceae-Myrtaceae forest, Lithocarpus spp. (Fagaceae) were dominant and contributed nearly half of the basal area (Table 4, Appendix). Among their four species, L. menadoensis and L. celebicus were most abundant. The Myrtaceae were most species-rich (8 spp.) and thus among the most prominent families.

Several tree families showed high importance only at upper montane elevations and differentiated these high elevation forests from the mid-montane forests. In these coniferMyrtaceae forests, the Phyllocladaceae and Podocarpaceae largely replaced the Fagaceae in dominance and held together about a third of both stand basal area and total number of stems. Phyllocladus hypophylla (Phyllocladaceae) was most abundant, followed by Dacrycarpus steupii (Podocarpaceae). The Myrtaceae were the most important family with 5 species, high stem density and large basal area. The Fagaceae were less species-rich at upper-montane than at mid-montane elevations, but had still a large basal area. Lithocarpus havilandii was the most abundant species of the Fagaceae at the upper-montane level, but was less important in the mid-montane forest. The Paracryphiaceae, Dicksoniaceae, Ericaceae and Trimeniaceae were conspicuous elements of the upper montane forest.

Phytogeographical patterns

The complete data set included 28\% new distribution records for the island of Sulawesi (24 spp.), and 30\% new records for the Central Sulawesi province (26 spp.) (Table 4, Appendix). Seven of the new records for Sulawesi had before only been known from mountain peaks either on New Guinea or on Mindanao in the Philippines. Ficus sulawesiana (Moraceae) was a new species discovered. Species endemic to Sulawesi made up 14 of the total of 87 taxa (16\%).

The highest observed and expected numbers of tree species occurrences ( 82 and $78 \%$, respectively, based on the $71 \mathrm{spp}$. assigned to valid species names) were related to the nearest neighbour islands, Borneo and Maluku, and to endemics of Sulawesi (Table 3). 
Table 2 Family Importance Values (FIV) based on number of species, number of individuals $\left(n \mathrm{ha}^{-1}\right)$ and basal area $\left(\mathrm{m}^{2} \mathrm{ha}^{-1}\right)$ of all trees $\geq 2 \mathrm{~cm}$ d.b.h. at Mt Nokilalaki (N2, N1; c. $1800 \mathrm{~m}$ a.s.l.) and Mt Rorekautimbu (R1, R2; c. $2400 \mathrm{~m}$ a.s.l.) in Sulawesi

\begin{tabular}{|c|c|c|c|c|c|c|}
\hline & & $\mathrm{N} 2$ & N1 & $\mathrm{R} 1$ & $\mathrm{R} 2$ & DCA scores \\
\hline 1 & Celastraceae & 0.0 & 2.8 & 0.0 & 0.0 & -1.4412 \\
\hline 2 & Cyatheaceae & 0.0 & 3.4 & 0.0 & 0.0 & -1.4412 \\
\hline 3 & Hamamelidaceae & 0.0 & 6.1 & 0.0 & 0.0 & -1.4412 \\
\hline 4 & Juglandaceae & 0.0 & 12.0 & 0.0 & 0.0 & -1.4412 \\
\hline 5 & Magnoliaceae & 0.0 & 17.4 & 0.0 & 0.0 & -1.4412 \\
\hline 6 & Sapotaceae & 0.0 & 3.1 & 0.0 & 0.0 & -1.4412 \\
\hline 7 & Staphyleaceae & 0.0 & 3.2 & 0.0 & 0.0 & -1.4412 \\
\hline 8 & Thymelaeaceae & 0.0 & 3.2 & 0.0 & 0.0 & -1.4412 \\
\hline 9 & Melastomataceae & 8.6 & 14.8 & 0.0 & 0.0 & -1.3012 \\
\hline 10 & Icacinaceae & 3.2 & 3.6 & 0.0 & 0.0 & -1.2619 \\
\hline 11 & Phyllanthaceae & 3.2 & 3.5 & 0.0 & 0.0 & -1.2592 \\
\hline 12 & Oleaceae & 3.8 & 4.1 & 0.0 & 0.0 & -1.2579 \\
\hline 13 & Apocynaceae & 3.9 & 0.0 & 0.0 & 0.0 & -1.0602 \\
\hline 14 & Calophyllaceae & 4.8 & 0.0 & 0.0 & 0.0 & -1.0602 \\
\hline 15 & Moraceae & 3.8 & 0.0 & 0.0 & 0.0 & -1.0602 \\
\hline 16 & Sabiaceae & 3.7 & 0.0 & 0.0 & 0.0 & -1.0602 \\
\hline 17 & Styracaceae & 10.2 & 0.0 & 0.0 & 0.0 & -1.0602 \\
\hline 18 & Fagaceae & 94.1 & 56.8 & 33.4 & 8.3 & -0.2742 \\
\hline 19 & Escalloniaceae & 7.0 & 9.7 & 6.6 & 0.0 & -0.0977 \\
\hline 20 & Symplocaceae & 16.6 & 19.1 & 10.7 & 3.6 & -0.0045 \\
\hline 21 & Rubiaceae & 14.8 & 9.3 & 10.5 & 6.8 & 0.6647 \\
\hline 22 & Myrtaceae & 81.4 & 81.1 & 44.4 & 68.0 & 0.682 \\
\hline 23 & Theaceae & 13.7 & 26.9 & 20.1 & 17.3 & 0.8982 \\
\hline 24 & Proteaceae & 3.5 & 0.0 & 4.0 & 0.0 & 0.9985 \\
\hline 25 & Clethraceae & 0.0 & 3.2 & 6.1 & 0.0 & 1.2368 \\
\hline 26 & Winteraceae & 3.8 & 3.8 & 5.6 & 8.2 & 1.4944 \\
\hline 27 & Euphorbiaceae & 3.2 & 0.0 & 2.9 & 3.3 & 1.5583 \\
\hline 28 & Rosaceae & 4.0 & 0.0 & 5.5 & 4.1 & 1.6501 \\
\hline 29 & Rutaceae & 3.2 & 0.0 & 3.2 & 5.9 & 1.858 \\
\hline 30 & Lauraceae & 3.2 & 3.2 & 12.0 & 13.7 & 1.9611 \\
\hline 31 & Myrsinaceae & 3.3 & 3.2 & 13.1 & 21.1 & 2.1332 \\
\hline 32 & Paracryphiaceae & 3.2 & 3.6 & 17.3 & 23.2 & 2.1584 \\
\hline 33 & Chloranthaceae & 0.0 & 0.0 & 3.2 & 0.0 & 2.244 \\
\hline 34 & Cunoniaceae & 0.0 & 0.0 & 3.3 & 0.0 & 2.244 \\
\hline 35 & Podocarpaceae & 0.0 & 3.2 & 33.1 & 27.1 & 2.3748 \\
\hline 36 & Dicksoniaceae & 0.0 & 0.0 & 16.6 & 4.3 & 2.3786 \\
\hline 37 & Ericaceae & 0.0 & 0.0 & 11.2 & 5.1 & 2.4487 \\
\hline 38 & Myricaceae & 0.0 & 0.0 & 6.3 & 3.9 & 2.4941 \\
\hline 39 & Trimeniaceae & 0.0 & 0.0 & 7.7 & 12.7 & 2.6512 \\
\hline 40 & Elaeocarpaceae & 0.0 & 0.0 & 3.6 & 7.4 & 2.684 \\
\hline 41 & Phyllocladaceae & 0.0 & 0.0 & 19.6 & 44.5 & 2.6981 \\
\hline 42 & Aquifoliaceae & 0.0 & 0.0 & 0.0 & 3.2 & 2.8981 \\
\hline
\end{tabular}


Table 2 continued

\begin{tabular}{llccccc}
\hline & & $\mathrm{N} 2$ & $\mathrm{~N} 1$ & $\mathrm{R} 1$ & $\mathrm{R} 2$ & DCA scores \\
\hline 43 & Daphniphyllaceae & 0.0 & 0.0 & 0.0 & 5.0 & 2.8981 \\
44 & Loganiaceae & 0.0 & 0.0 & 0.0 & 3.3 & 2.8981 \\
- & non det & 1.0 & 3.3 & 1.8 & 0.0 & - \\
& FIV sum & 300.00 & 300.00 & 300.00 & 300.00 & \\
\hline
\end{tabular}

Bold letters indicate families with FIV $\geq 10$. Families sorted by scores of first detrended correspondence analysis (DCA) axis (eigenvalue 0.411) using FIV as quantitative values

Table 3 Observed and expected tree species occurrences in seven nearest neighbour islands to Sulawesi, including Sulawesi itself for endemics

\begin{tabular}{|c|c|c|c|c|c|c|c|}
\hline Code & $\begin{array}{l}\text { Biogeographical } \\
\text { region }\end{array}$ & $\begin{array}{l}\text { Distance } \\
(\mathrm{km})\end{array}$ & $\begin{array}{l}\text { Observed tree } \\
\text { species Mt } \\
\text { Nokilalaki } \\
(42 \mathrm{spp})\end{array}$ & $\begin{array}{l}\text { Observed tree } \\
\text { species Mt } \\
\text { Rorekautimbu } \\
(45 \mathrm{spp})\end{array}$ & $\begin{array}{l}\text { Observed } \\
\text { tree } \\
\text { species } \\
\text { pool }(71 \\
\text { spp) }\end{array}$ & $\begin{array}{l}\text { Observed } \\
\text { tree } \\
\text { species } \\
\text { pool }(\%)\end{array}$ & $\begin{array}{l}\text { Probability } \\
\text { (expected } \\
\%)\end{array}$ \\
\hline 0 & Sulawesi & 0 & 9 & 9 & 14 & 0.20 & 0.20 \\
\hline 1 & Borneo & 725 & 22 & 17 & 32 & 0.45 & 0.32 \\
\hline 2 & Maluku & 884 & 8 & 8 & 12 & 0.17 & 0.26 \\
\hline 3 & Java & 1347 & 1 & 2 & 3 & 0.04 & 0.14 \\
\hline 4 & Philippines & 1687 & 0 & 4 & 4 & 0.06 & 0.06 \\
\hline 5 & Sumatra & 2254 & 1 & 0 & 1 & 0.01 & 0.02 \\
\hline 6 & Papuasia & 2402 & 1 & 5 & 5 & 0.07 & 0.01 \\
\hline
\end{tabular}

Biogeographical regions are sorted by ascending distance to the study area in Sulawesi. Probability (based on Poisson probability density) is related to the tree species pool observed in both studied sites (71 spp. assigned to valid species names)

Fewer nearest neighbour tree species were observed than expected in Java and more in Papuasia.

The likelihood analysis that one of the two studied forest areas $(\mathrm{N}, \mathrm{R})$ included more tree species with nearest neighbour distance to one of the seven islands than the other were not significant, but showed some contrasting trends in biogeographical affinities of the two forest communities (Fig. 2). The mid-montane forests showed the greatest similarity with the western Malesian islands of Sundaland, especially Borneo, whilst the upper-montane forests had a great eastern Malesian affinity with New Guinea and also to the Philippines. Endemics to Sulawesi and to Maluku, i.e. Wallacean distributed species, were of equal importance at both sites.

\section{Discussion}

Elevational patterns in high mountain tree community composition and structure

The high mountain forests in Sulawesi show divergent patterns related to different elevational belts, both in floristic composition and in community dominance of certain taxa. 

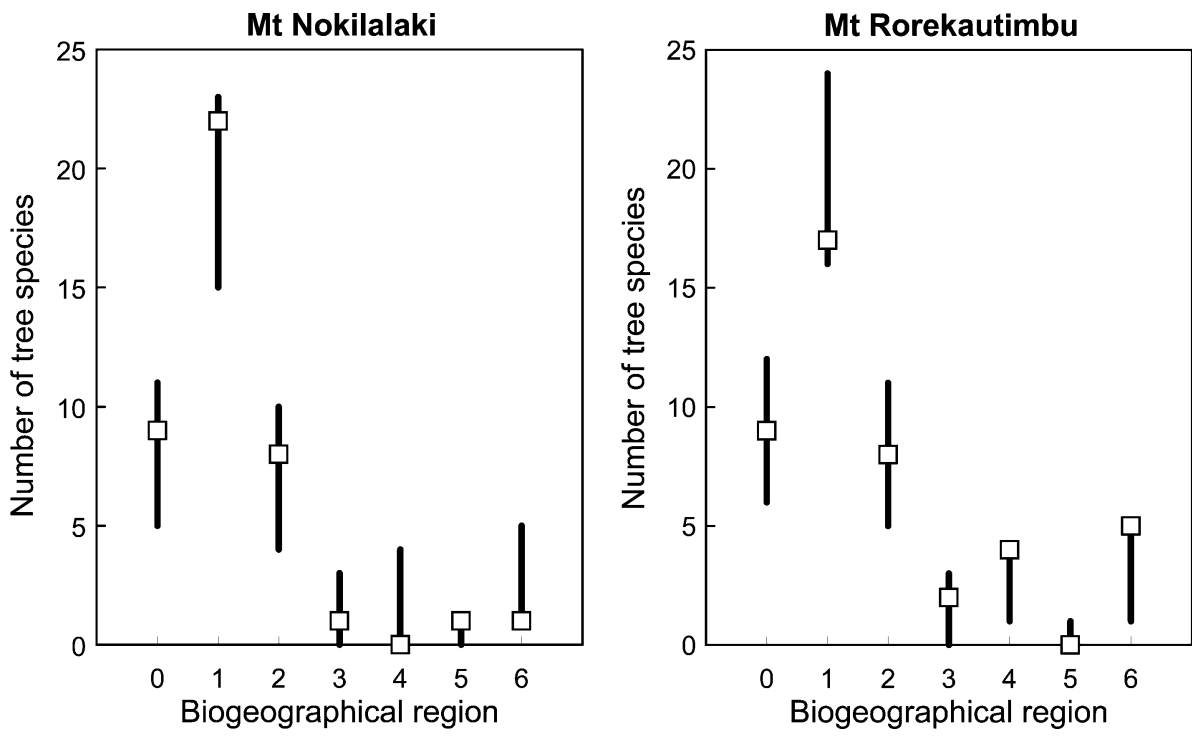

Fig. 2 Observed number of tree species (white squares) in the mid-montane forest at Mt Nokilalaki (42 spp.) and the upper montane forest at Mt Rorekautimbu (45 spp.) with nearest neighbour occurrences in seven Malesian biogeographical regions, and expected patterns (black bars) based on 1000 random samples from the combined tree species pool $(71 \mathrm{spp}$.). Biogeographical regions are sorted by ascending nearest neighbour distances (cf. Table 3)

In the Malesian mountain flora, within the montane zone sensu stricto (1600-2400 m a.s.1.), a major species shift indicates an orographic boundary at about $2000 \mathrm{~m}$ a.s.l. (van Steenis 1972). The present study supports these findings by showing a species shift between mid- and upper montane elevations (1800-2400 m a.s.1.), with only 18 species in common considering the total data set of 87 tree species (21\%). Further, the mossy aspect of the forest at upper montane elevations (Gradstein and Culmsee 2010) also provides evidence for the elevational differences between the investigated forests.

In the Fagaceae-Myrtaceae forests surveyed at mid-montane elevations, the Fagaceae play a key role. While four species of Lithocarpus contributed nearly half of the stand basal area, the importance of the family decreased at upper montane elevations in favour of the Podocarpaceae and Phyllocladaceae. Previous studies in Lore Lindu National Park, Central Sulawesi, showed that the Fagaceae were of comparable overall importance at lower montane elevations (at $1400 \mathrm{~m}$ a.s.l.), but became less important at submontane elevations (at $1050 \mathrm{~m}$ a.s.1.) (Culmsee and Pitopang 2009). In the lower and mid-montane forests of Sulawesi, the Fagaceae make up more than half of the aboveground biomass and constitute important carbon stocks (Culmsee et al. 2010). The community dominance of Fagaceae is a common phenomenon throughout Malesia. The species density and evolutionary centres of the tropical genera Castanopsis and Lithocarpus are situated in Western Malesia (Manos and Stanford 2001; Cannon and Manos 2003), with highest numbers of species and endemism in Borneo (Soepadmo 1972). Forest surveys at mid-montane elevations over quaternary and sedimentary substrates on Mt Kinabalu, Borneo, showed that the Fagaceae were represented with 9 and 20 species, respectively, including the genera Castanopsis, Lithocarpus, Quercus and Trigonobalanus (Aiba et al. 2002; plots 17Q, 17S). In midmontane forests on Mt Pangrango, Java, the Fagaceae occurred with fewer species, but 
were also a common component (Yamada 1977). Within-family species richness rapidly declines east of Wallace's line, but the relatively few species may dominate tree communities in Sulawesi as well as in New Guinea. In New Guinea, a single species, Castanopsis acuminatissima, locally forms pure stands in lower to mid-montane elevations (Soepadmo 1972; Johns et al. 2007).

The Podocarpaceae are important components of tropical and southern hemisphere moist forests, with their species density centre in Southeast Asia and Australasia, but extending also into the tropical American and African highlands (de Laubenfels 1988). While many species have a broad elevational range (de Laubenfels 1988; Keßler et al. 2002), the family is particularly well represented and may gain community dominance in upper montane mossy forests (Culmsee et al. 2010) and on ultramafic soils (Aiba et al. 2002; Proctor 2003). The community dominance of the conifer families in the upper montane forests in Sulawesi reflects the situation observed in other high mountains of Malesia, especially in Borneo and New Guinea (Grubb and Stevens 1985; Aiba and Kitayama 1999; Johns et al. 2007). Compared to upper montane forests at Mt Kerigomna and 20 other high mountains in New Guinea (Grubb and Stevens 1985), the upper montane forest in Sulawesi shows high similarity not only in the high abundance of Podocarpaceae, but also in the frequent occurrence of several high mountain tree taxa, such as Daphniphyllum gracile (Daphniphyllaceae), micro- and nanophyllic species of Rapanea (Myrsinaceae), Drimys piperita (Winteraceae), and the Australasian elements Quintinia sp. and Sphenostemon papuanum (Paracryphiaceae).

The phytogeography of high mountain forests of Sulawesi in the Malesian context

A survey of plant species diversity and endemism across five major Malesian islands has indicated that vascular plant diversity and the rate of plant species endemism (12\%) in Sulawesi were relatively low and did not reflect the long-term isolation of the island (Roos et al. 2004). Considering the relatively small regional data set of 71 species identified to valid species names in the present study, the rate of $20 \%$ endemics is substantially higher. Cannon et al. (2007) pointed out that the low diversity and endemism rates found for Sulawesi might be related to the fact that collection rates on Sulawesi are among the lowest in Indonesia, and taxonomic studies of this region are limited. In fact, the high number of new distribution records for Sulawesi and the recent discovery of new species, even in well-studied vascular plant families like the Meliaceae and Moraceae (Mabberley et al. 1995; Berg and Corner 2005), as documented in this and previous studies (Culmsee 2008; Culmsee and Pitopang 2009; Berg and Culmsee unpublished data), suggest that both the Linnean and Wallacean shortfalls apply for Sulawesi, i.e. inadequacies in taxonomic and distributional data (Whittaker et al. 2005).

The Southeast Asia and Southwest Pacific region is characterised by extremely high rates of plate convergence (Hall 2009). Their biogeographical region Wallacea, including Sulawesi, the Moluccas and the Lesser Sunda Islands, has evolved from the collision between Australia and Sundaland. In the tectonically quiet region of Sundaland, the largely tropical genera of the Fagaceae emerged at least 40 Ma (Manos and Stanford 2001; Cannon and Manos 2003). Only the western parts of Sulawesi originated from Sundaland. The northern and eastern parts of Sulawesi were formed by volcanic activity and land masses continuously moving north-westwards during the Tertiary after the collision between the East Philippines-Halmahera Arc and northern Australian margin of New Guinea (Hall 2002). While the Fagaceae immigrated eastwards from their evolutionary centre in Sundaland, the Antarctic Podocarpaceae immigrated north-westwards 
(de Laubenfels 1988). In the present study, it was found that the highest number of species were either Wallacean (Sulawesi endemics or nearest neighbours to Maluku) or nearest neighbours to Sundaland (Borneo), which reflects the complex palaeogeography of the island. These results are in line with those documented by Roos et al. (2004) who found that Sulawesi possesses an unusual biogeographical composition of the flora, comprising eastern and western Malesian centred floristic elements.

The tree assemblage at mid-montane elevations in Sulawesi had greater affinity to western Malesia, especially Borneo, whilst that at upper montane elevations showed a peculiar enrichment with Papuasian elements. Certainly, biological processes such as divergence events, dispersal distances and plant migration potential are important factors that influence regional floristic composition, but these have been mainly investigated for Southeast Asian and Southwest Pacific lowland floras (e.g. Muellner et al. 2008; Corlett 2009). They may coincide with historical patterns in land connections and possible migration routes of plants as well as in the formation of mountains. The late Miocene, about $10 \mathrm{Ma}$, provided the easiest connections between Australia and Sulawesi and relatively extensive areas of possible land. At the same time, the elevation of New Guinea began, but the mountains of New Guinea, the Moluccas and Sulawesi, have only been at their present heights since $5 \mathrm{Ma}$. Sulawesi was also probably connected to Borneo via Java until the Pliocene, but only by way of small islands. Especially this coincidence of suitable elevational belts may have led to the present-day upper montane flora in Sulawesi that is more similar to eastern Malesia and more isolated from western Malesia. Thus, our study shows, that biogeographical patterns become more pronounced when considering species distributions on the tree community-level for different elevations.

Acknowledgments Field-work was kindly supported by the Collaborative Research Centre SFB 552 at the University of Göttingen, funded by the German Research Foundation DFG. The visit of the first author to the National Herbarium of the Netherlands, University of Leiden, was facilitated by courtesy of EU-SYNTHESYS grant NL-TAF 3317; she would like to thank specialists for their help in plant identification and discussion of difficult taxa, especially at Leiden M.M.J. van Balgooy, C.C. Berg, H.P. Nooteboom, at Kew: M.J.E. Coode, and at Göttingen J. Kluge and M. Lehnert. We would like to thank Katrin Meyer and Yann Clough (both University of Göttingen) for their kind help with null-models.

Open Access This article is distributed under the terms of the Creative Commons Attribution Noncommercial License which permits any noncommercial use, distribution, and reproduction in any medium, provided the original author(s) and source are credited.

\section{Appendix}

See Table 4. 


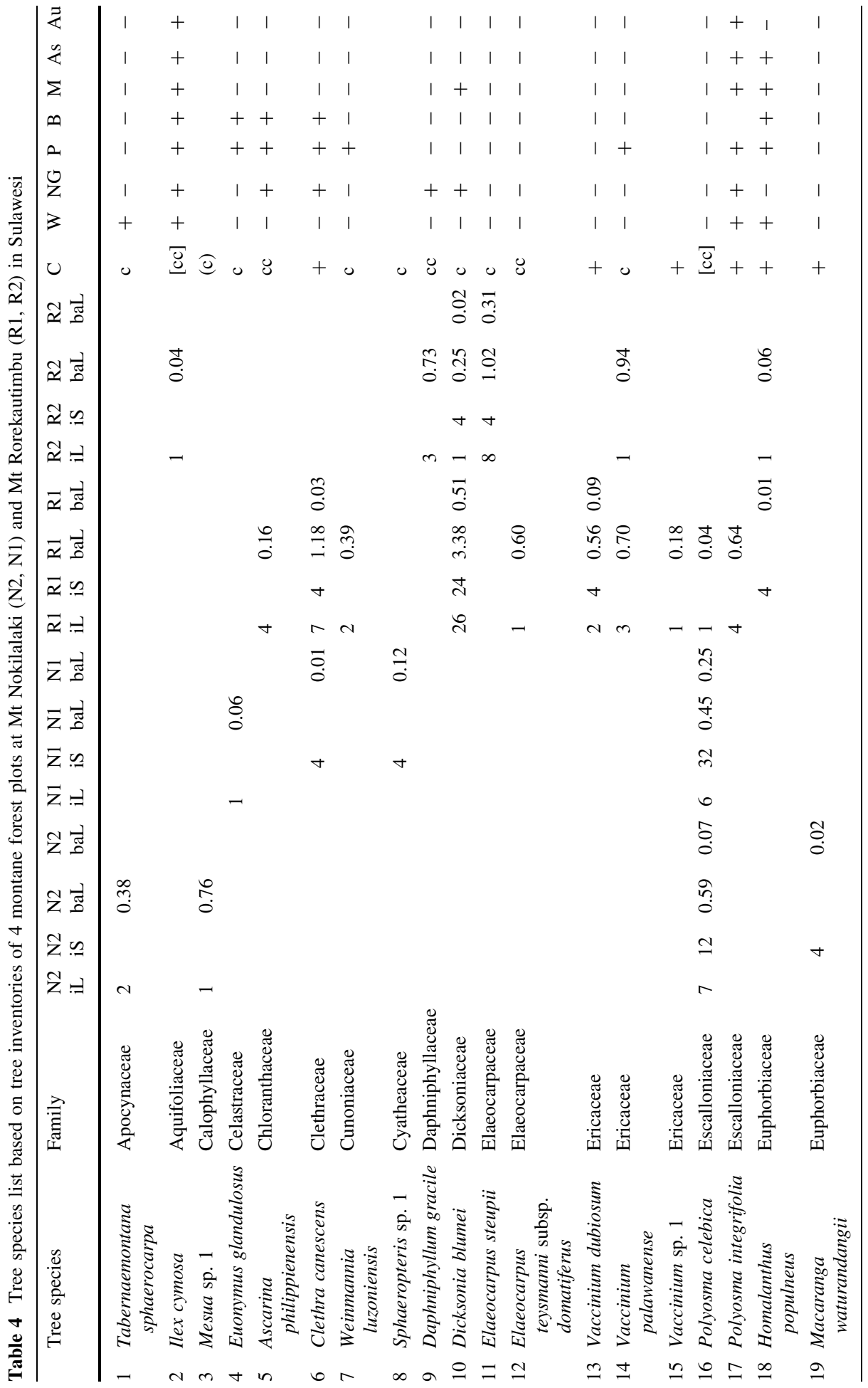




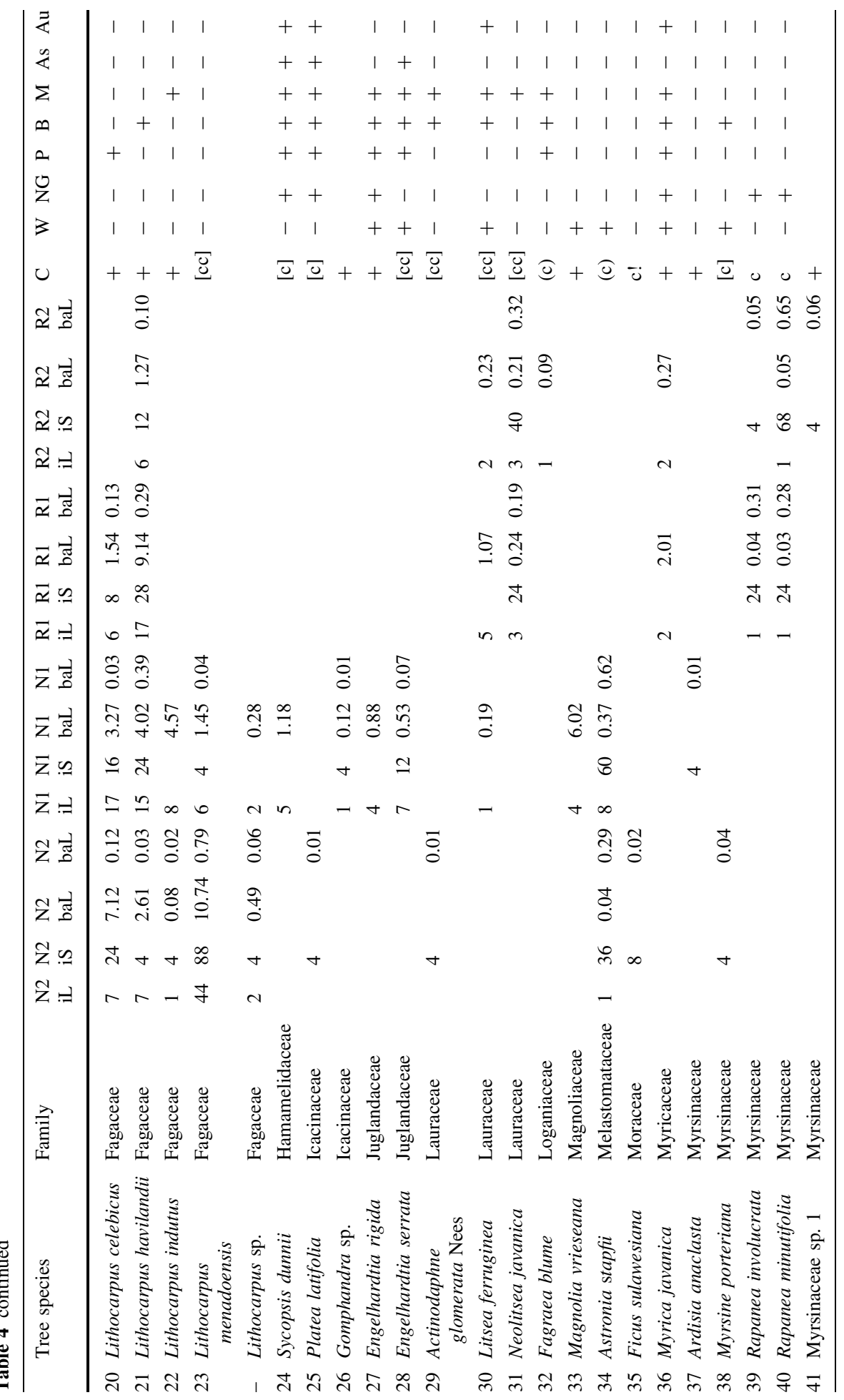




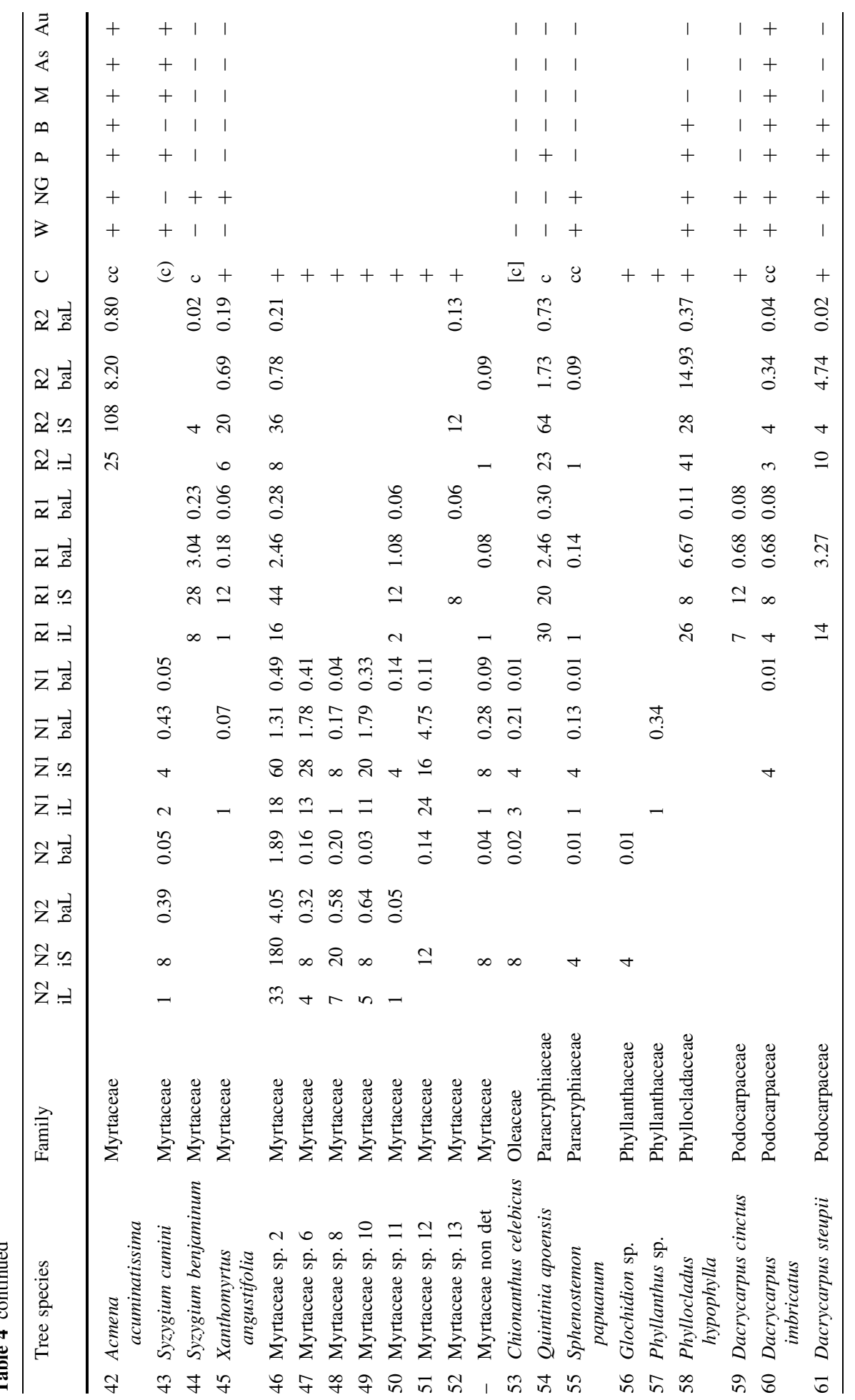




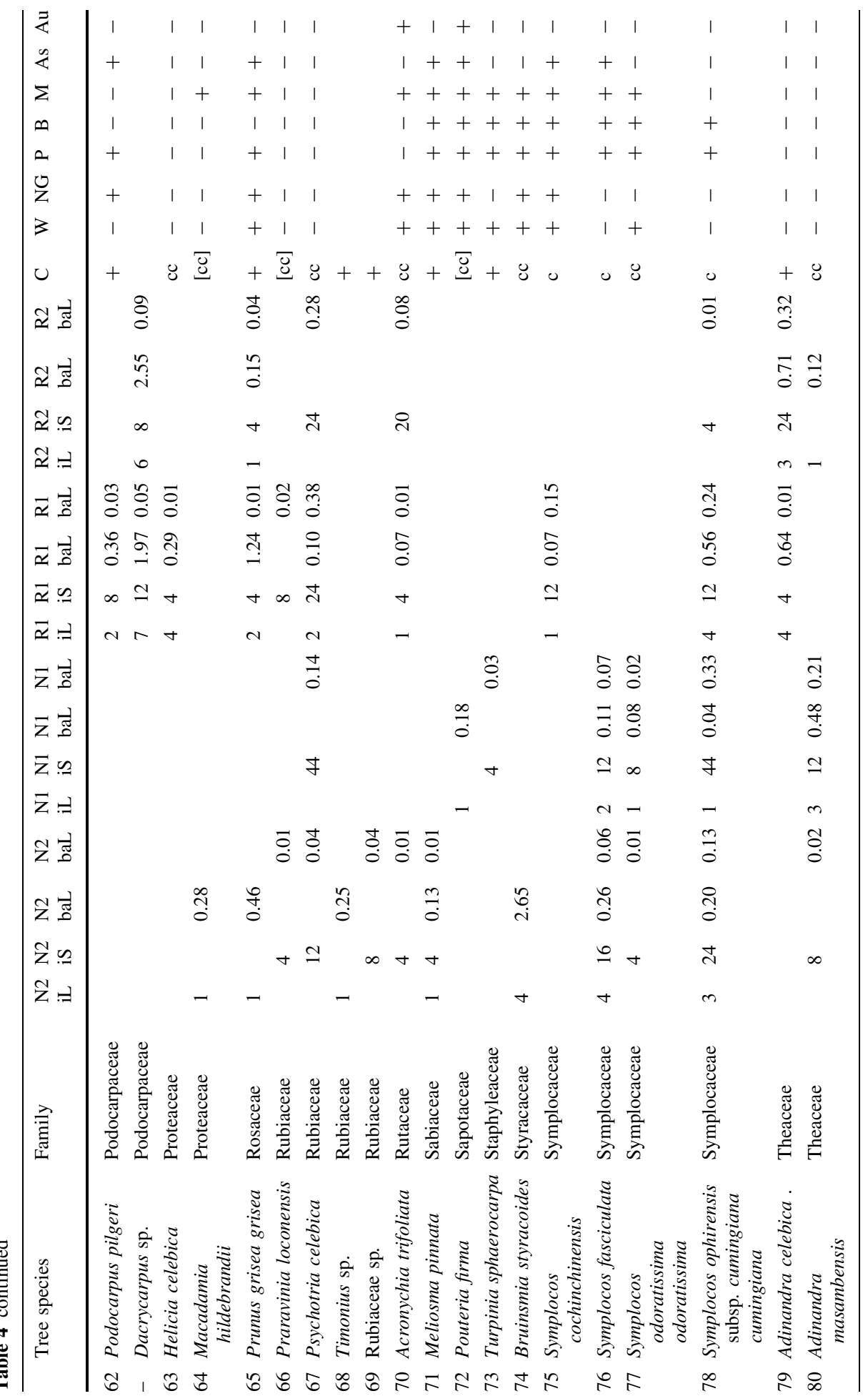




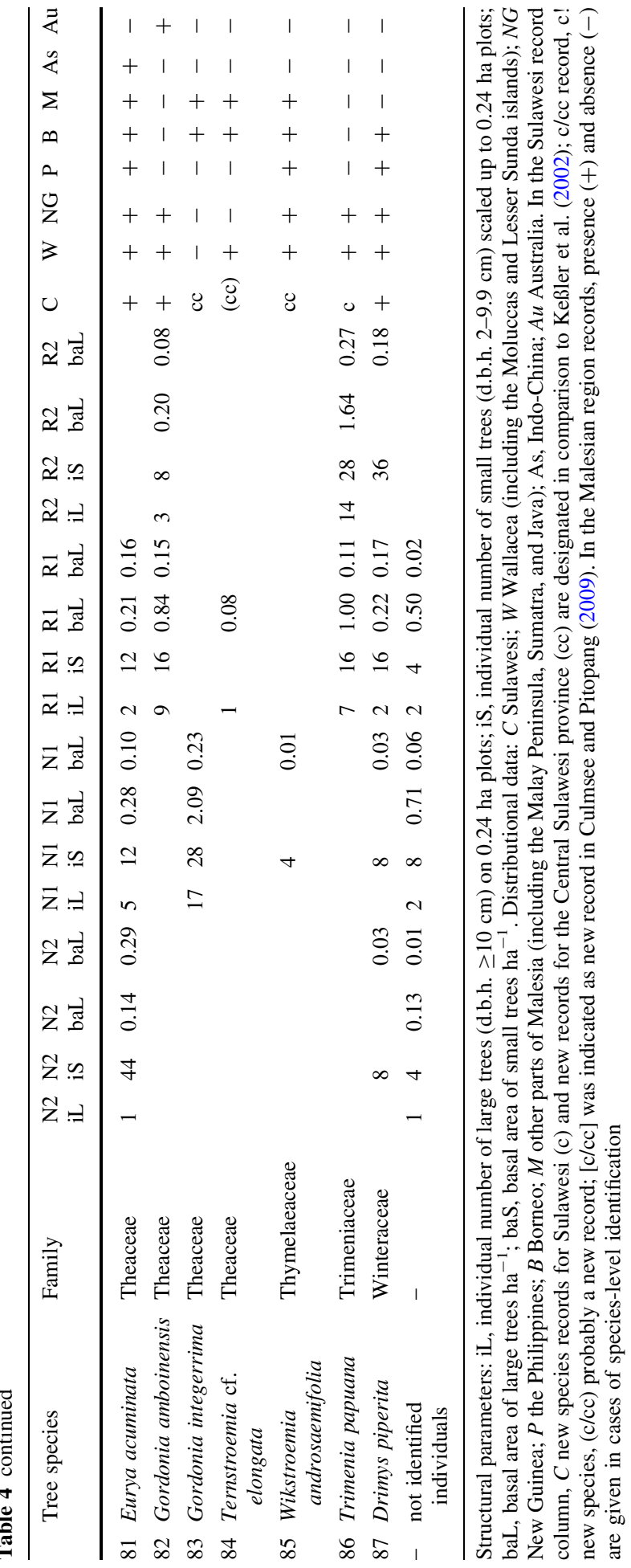




\section{References}

Aiba SI, Kitayama K (1999) Structure, composition and species diversity in an altitude-substrate matrix of rain forest tree communities on Mount Kinabalu, Borneo. Plant Ecol 140:139-157

Aiba SI, Kitayama K, Repin R (2002) Species composition and species-area relationships of trees in nine permanent plots in altitudinal sequences on different geological substrates of Mount Kinabalu. Sabah Parks Nat J 5:7-69

Airy Shaw HK (1983) The Euphorbiaceae of Central Malesia (Celebes, Moluccas, Lesser Sunda Is.). Kew Bull 37:1-40

Ashton PS (1988) Dipterocarp biology as a window to the understanding of tropical forest structure. Annu Rev Ecol Syst 19:347-370

Ashton PS (2003) Floristic zonation of tree communities on wet tropical mountains revisited perspectives in plant ecology. Evol Syst 6:87-104

Backer CA (1954) Myricaceae. Flora Malesiana, series 1, 4:277-279

Berg CC, Corner EJH (2005) Moraceae. Flora Malesiana, series 1, 17(2):1-730

Brummitt RK (2001) Plant taxonomic database standards No. 2, 2nd edn. World geographical scheme for recording plant distributions, 15 (ed 2), 137, 17 maps

Cannon CH, Manos PS (2003) Phylogeography of the Southeast Asian stone oaks (Lithocarpus). J Biogeogr 30:211-226

Cannon CH, Summers M, Harting JR, Keßler PJA (2007) Developing conservation priorities based on forest type, condition, and threats in a poorly known ecoregion: Sulawesi, Indonesia. Biotropica 39:747-759

Colwell RK (2006) EstimateS: statistical estimation of species richness and shared species from samples (software and user's guide), version 8. http://viceroy.eeb.uconn.edu/estimates. Accessed 6 January 2008

Corlett RT (2007) What's so special about Asian tropical forests? Curr Sci 93:1551-1557

Corlett RT (2009) Seed dispersal distances and plant migration potential in tropical East Asia. Biotropica 41:592-598

Culmsee H (2008) Dysoxylum quadrangulatum, and notes on Meliaceae in Sulawesi. Blumea 53:602-606

Culmsee H, Pitopang R (2009) Tree diversity in sub-montane and lower montane primary rain forests in Central Sulawesi. Blumea 54:119-123

Culmsee H, Leuschner C, Moser G, Pitopang R (2010) Forest aboveground biomass along an elevational transect in Sulawesi, Indonesia, and the role of Fagaceae in tropical montane rain forests. J Biogeogr 15 (in press)

de Laubenfels DJ (1988) Coniferales. Flora Malesiana, series 1, 10(3):337-453

Ding Hou (1972a) Thymelaeaceae. Flora Malesiana, series 1, 6:1-48

Ding Hou (1972b) Celastraceae. Flora Malesiana, series 1, 6:227-291

FAO (2006) World reference base for soil resources 2006. A framework for international classification, correlation and communication. World Soil Resour Rep 103:1-128

Fortune Hopkins HCF, Hoogland RD (2002) Cunoniaceae. Flora Malesiana, series 1, 16:53-165

Frahm JP, Gradstein SR (1991) An altitudinal zonation of tropical rain-forests using bryophytes. J Biogeogr 18:669-678

Gotelli NJ, Colwell RK (2001) Quantifying biodiversity: procedures and pitfalls in the measurement and comparison of species richness. Ecol Lett 4:379-391

Gradstein SR, Culmsee H (2010) Bryophyte diversity on tree trunks in montane forests of Central Sulawesi, Indonesia. Trop Bryol 31:95-105

Grubb PJ, Stevens PF (1985) The forests of the Fatima Basin and Mt Kerigomna, Papua New Guinea with a review of montane and subalpine rainforests in Papuasia. Australian National University, Canberra

Hall R (2002) Cenozoic geological and plate tectonic evolution of SE Asia and the SW Pacific: computerbased reconstructions, model and animations. J Asian Earth Sci 20:353-431

Hall R (2009) Southeast Asia's changing palaeogeography. Blumea 54:148-161

Hijmans RJ, Cameron SE, Parra JL, Jones PG, Jarvis A (2005) Very high resolution interpolated climate surfaces for global land areas. Int J Climatol 25:1965-1978

Holttum RE (1963) Cyatheaceae. Flora Malesiana, series 2, 1(2):65-176

Huang T (1997) Daphniphyllaceae. Flora Malesiana, series 1, 13:145-168

IPNI (2009) International plant names index. http://www.ipni.org. Accessed 30 Nov 2009

Jacobs M (1972) Juglandaceae. Flora Malesiana, series 1, 6:143-154

Johns RT, Shea GA, Vink W, Puradyatmika P (2007) Montane vegetation of Papua. In: Marshall AJ, Beehler BM (eds) The ecology of Papua. Periplus, Singapore, pp 977-1024

Kalkman C (1993) Rosaceae. Flora Malesiana, series 1, 11(2):227-351 
Keng H (1984) Florae malesianae precursores-LVIII, part two, the genus gordonia (Theaceae) in Malesia. Gard Bull Singapore 37:1-47

Keßler PJA, Bos MM, Sierra Daza SEC, Kop A, Willemse LPM, Pitopang R, Gradstein SR (2002) Checklist of woody plants of Sulawesi, Indonesia. Blumea Suppl 14:1-160

Kessler M, Keßler P, Gradstein SR, Bach K, Schmull M, Pitopang R (2005) Tree diversity in primary forest and different land use systems in Central Sulawesi, Indonesia. Biodivers Conserv 14:547-560

Körner C (2000) Why are there global gradients in species richness? mountains might hold the answer. Trends Ecol Evol 15:513-514

Körner C (2007) The use of 'altitude' in ecological research. Trends Ecol Evol 22:569-574

Mabberley DJ, Pannell CM, Sing AM (1995) Meliaceae. Flora Malesiana, series 1, 12:1-407

Manos PS, Stanford AM (2001) The historical biogeography of Fagaceae: tracking the Tertiary history of temperate and subtropical forests on the Northern Hemisphere. Int J Plant Sci 162:S77-S93

Maxwell JF, Veldkamp JF (1990) Notes on the Astronieae (Melastomataceae)-I. Astrocalyx, Astronia. Blumea 35:71-114

Middleton DJ (2007) Apocynaceae (subfamilies Rauvolfioideae and Apocynoideae). Flora Malesiana, series $1,18: 1-474$

Mori SA, Boom BM, De Carvalho A, Dos Santos TS (1983) Southern Bahian moist forests. Bot Rev 49:155-232

Muellner AN, Pannell CM, Coleman A, Chase MW (2008) The origin and evolution of Indomalesian, Australasian and Pacific island biotas: insights from Aglaieae (Meliaceae, Sapindales). J Biogeogr 35:1769-1789

Munzel U, Hothorn LA (2001) A unified approach to simultaneous rank test procedures in the unbalanced oneway layout. Biom J 43:553-569

Myers N, Mittermeier RA, Mittermeier CG, da Fonseca GAB, Kent J (2000) Biodiversity hotspots for conservation priorities. Nature 403:853-858

Nooteboom HP (1977) Symplocaceae. Flora Malesiana, series 1, 8(2):205-274

Nooteboom HP (1985) Notes on Magnoliaceae with a revision of Pachylarnax and Elmerrillia and the Malesian species of Manglietia and Michelia. Blumea 31:65-121

Nooteboom HP (2005) Symplocaceae of the old world: descriptions, illustrations, identification, and information retrieval. http://www.nationaalherbarium.nl. Accessed on 10 January 2010

Ohsawa M (1993) Latitudinal pattern of mountain vegetation zonation in southern and eastern Asia. J Veg Sci 4:13-18

Philipson WR (1986) Trimeniaceae. Flora Malesiana, series 1, 10(2):327-333

Primack R, Corlett R (2006) Tropical rain forests. An ecological and biogeographical comparison. Blackwell, Malden

Proctor J (2003) Vegetation and soil and plant chemistry on ultramafic rocks in the tropical Far East. Perspect Plant Ecol Evol Syst 6:105-124

R Development Core Team (2010) R: A language and environment for statistical computing. R Foundation for Statistical Computing, Vienna, Austria. ISBN 3-900051-07-0, http://www.R-project.org

Roos MC, Keßler PJA, Gradstein SR, Baas P (2004) Species diversity and endemism of five major Malesian islands: diversity-area relationships. J Biogeogr 31:1893-1908

Scott AJ (1978) A revision of Xanthomyrtus (Myrtaceae). Kew Bull 33:461-484

Sleumer H (1958) Proteaceae. Flora Malesiana, series 1, 5:147-206

Sleumer H (1971) Clethraceae. Flora Malesiana, series 1, 7(1):139-150

Sleumer H (1972) Ericaceae. Flora Malesiana, series 1, 6:469-914

Sleumer H (1976) Icacinaceae. Flora Malesiana, series 1, 6:1-87

Sleumer H (1986) A revision of the genus Rapanea Aubl. (Myrsinaceae) in New Guinea. Blumea 31:245-269

Sodhi NS, Koh LP, Brook BW, Ng PKL (2004) Southeast Asian biodiversity: an impending disaster. Trends Ecol Evol 19:655-660

Soepadmo E (1972) Fagaceae. Flora Malesiana, series 1, 7(2):265-403

Stevens PF (2001 onwards) Angiosperm Phylogeny Website. Version 9, June 2008. http://www.mobot.org/ MOBOT/research/APweb/. Accessed 10 April 2009

ter Braak CJF, Šmilauer P (2002) Canoco reference manual and CanoDraw for Windows user's guide. Software for Canocical Community Ordination, version 4.5. Biometris, Wageningen and Ceské Budějovice

van Balgooy MMJ, Tantra IGM (1986) The vegetation in two areas in Sulawesi, Indonesia. Buletin Penelitian Hutan, Bogor

van der Linden BL (1972) Staphyleaceae. Flora Malesiana, series 1, 6:49-59

van Steenis CGGJ (1954) Styracaceae. Flora Malesiana, series 1, 4:49-56 
van Steenis CGGJ (1972) The mountain flora of Java. Brill, Leiden

van Steenis CGGJ (1984) Floristic altitudinal zones in Malesia. Bot J Linn Soc 89:289-292

van Steenis CGGJ (1986) Sphenostemonaceae. Flora Malesiana, series 1, 10(2):145-149

Verdcourt B (1986) Chloranthaceae. Flora Malesiana, series 1, 10(2):123-144

Wallace AR (1869) The Malay Archipelago. Harper and Brothers, New York

Webb CO, Slik JWF, Triono T (2010) Biodiversity inventory and informatics in Southeast Asia. Biodivers Conserv 19:955-972

Whittaker RJ, Araújo MB, Jepson P, Ladle RJ, Watson JEM, Willis KJ (2005) Conservation biogeography: assessment and prospect. Divers Distrib 11:3-23

WorldClim (2006) WorldClim version 1.4, bioclim ESRI grids 30 arc-seconds $(\sim 1 \mathrm{~km})$ resolution. http://www.worldclim.org. Accessed 6 Aug 2008

Yamada I (1977) Forest ecological studies of the montane forest of Mt. Pangrango, West Java. IV. Floristic composition along the altitude. South East Asian Stud 15:226-254 